\title{
Chicken Hybrid Imagery on Late Iron Age Coinage in Northern Gaul and Southern England during the Iron Age-Roman Transition
}

\author{
Mike P. Feider, Ellen Hambleton, and Mark Maltby
}

\section{Introduction}

Many zooarchaeological studies have principally focused on the economic exploitation of animals at the expense of examining the social relationships between humans and animals. Gradually, however, social zooarchaeology is increasingly using evidence from other disciplines, particularly anthropology, to furnish deeper discussions of these relationships (e.g. Morris and Maltby 2010; Russell 2014; Sykes 2014). Naomi Sykes has championed the adoption of social zooarchaeology to address 'the most fundamental issues concerning past societies: how people behaved and how they thought' (2014: 1). Importantly, social zooarchaeology frameworks (e.g. Overton and Hamilakis 2013; Sykes 2014) place animals at the centre of this discourse, recognising that animals and their autonomous actions, inherent behaviours, appearance, physical and vocal presence, and indeed their individual quirks, are integral to the negotiation and mutual construction of human-animal (or animal-human!) relationships. The concept that animals have agency is an important aspect in this approach and the social contract, as defined by Kristin Armstrong Oma (2010), is more likely to be reflected in imagery rather than bones. Concepts of human and animal are constantly evolving and have to be examined in this context (Braidotti 2018: 6-7). Some of the images discussed in this paper reflect hybridisation between humans and non-humans, which has relevance to the focus of this volume. This is a posthuman, nonanthropocentric 'multispecies' approach, and we adopt it here in our exploration of the imagery of chickens and chicken-human hybrids on later Iron Age coinage.

Zooarchaeologists have also increasingly realised that human-animal relationships can be explored through other media rather than the bones themselves. Chickens were introduced into western Europe during the Iron Age and possible reasons for, and impact of, their introduction has recently been considered (Sykes 2012; Maltby et al. 2018; Pitt et al. 2019). However, most of the discussion has been based primarily on zooarchaeological data. The relationship between chickens and humans is also reflected in the material culture of this period and region, and it is the investigation of material culture, specifically locally distinct groups of late Iron Age coins depicting chicken-human hybrids, which forms the basis of this paper. We take a posthuman approach, drawing on aspects of 'new materialism', recognising that material objects can act as surrogate people (Harris and Cipolla 2017: 76). It is this aspect of the coins discussed in this paper that is considered in relation to their role in Belgic Gaul, where the chicken and chicken-human images on the coins may have provoked responses that served the ideological purpose of their makers. Importantly, we recognise that objects themselves have agency, often divorced from the original intent of their human makers (Harris and Cipolla 2017: 73), and it is this aspect that we consider in relation to the chicken and chicken-human imagery on coins from Britain. This study emphasises the importance of contextual archaeology as well as the 'post-anthropocentric' (Ferrando 2013: 29) interpretation of non-human animals, images, and objects and their interactions; we explore how this manifests in the context of the early Roman world - especially at the periphery of the empire.

During the Late Iron Age, a series of images depicting an unusual hybrid of a chicken with a human face on its belly became the earliest native chicken imagery produced in northwest Europe. These images appear on a very geographically and temporally restricted set of coins from Belgic Gaul and southeast England, and represent the earliest native chicken imagery in that part of the world. Other coins from the period include images of animals such as horses and boars (de Jersey 2006: 119); strong, powerful creatures whose inclusion is fairly understandable. The use of a chicken is less explicable and becomes even more complicated by the human face on the stomach of the bird. Miranda Aldhouse-Green (2004: 150) has noted that most of the human-animal hybrids from Late Iron Age northwest Europe are animals that share a close relationship with humans, and chickens possibly share an intimacy with humans greater than any other domestic species apart from pets. While this tradition of hybridisation goes some distance towards an explanation of this unusual image, the extremely limited geographical and temporal distribution of these coins permits a more focused exploration, and it is on this particular case study that this paper will concentrate. Why is the image that appears on some of the earliest base metal coins in this part of the world not just a chicken, but a chicken with a human face? 


\section{Gaul}
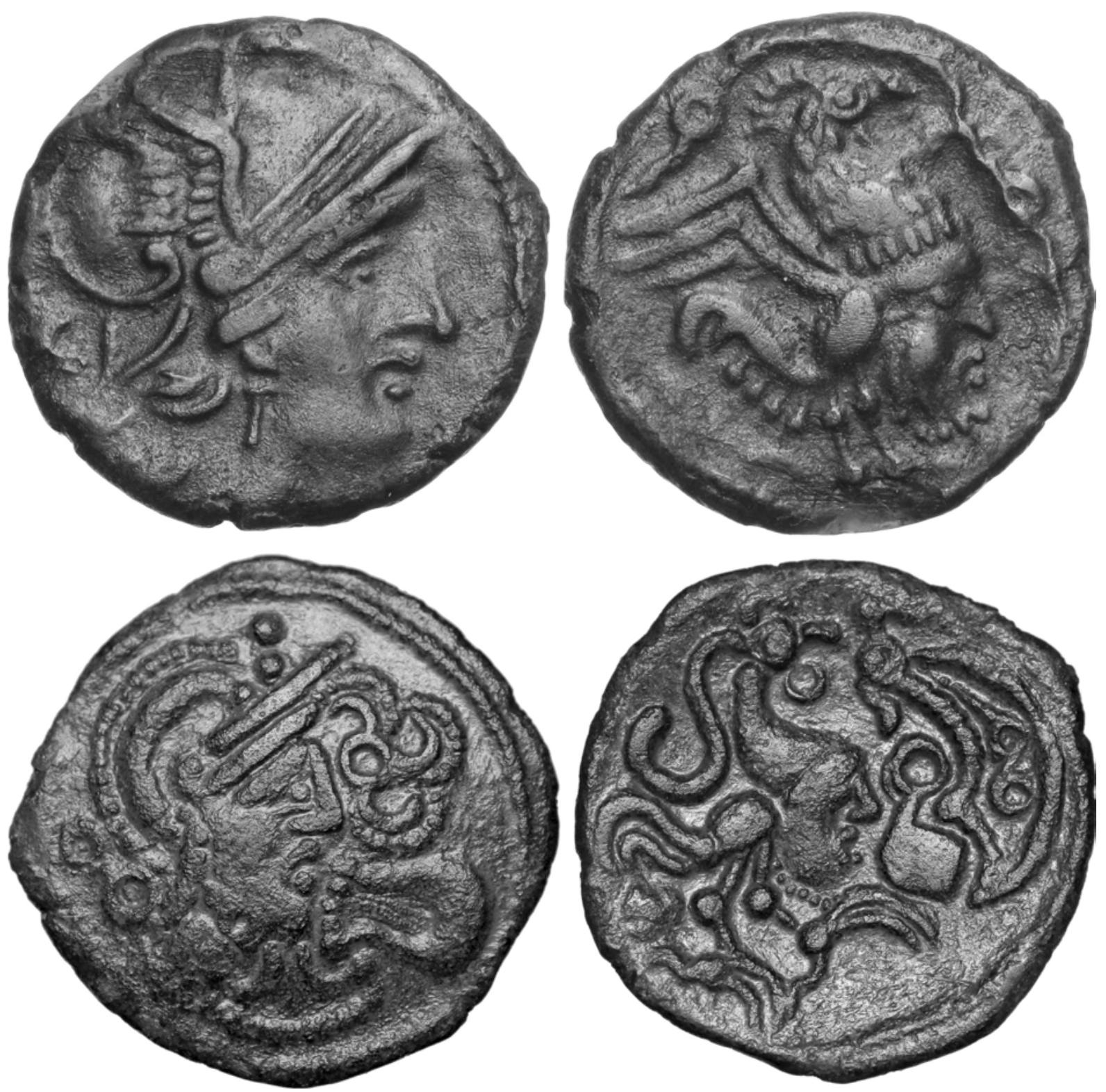

Figure 1: Belgic coins. Top: type DT 511, the so-called 'Bracquemont' type (www.cgb.fr, Lot 531625, June 2019). Bottom: type DT 516 (www.cgb.fr, Lot 423755, March 2017). (Courtesy of CGB Numismatic Paris - www.cgb.fr. Photo credit and copyright: CGB Numismatic Paris - www.cgb.fr).

The earliest coins of this type appear in Belgic Gaul in Haselgrove's Western zone, which includes the territories of the Ambiani, Atrebates, Bellovaci, and Veliocasses (Haselgrove 1999: 119). Using the typologies of Delestrée and Tache (2002), these coins are types DT 509 through DT 521 (Fig. 1).

Delestrée described these chicken-themed coins and their possible evolution over thirty years ago (Delestrée 1980), and has further clarified the typologies since (Delestrée and Tache 2002). For this investigation a detailed discussion of how they interrelate is not important, and a short summary of the earliest one and its variations will suffice.

Type 511, sometimes called the Bracquemont type, appears to be the earliest of this series. It is less stylised than the others, featuring a helmeted, female head on the obverse. The reverse image is of a cockerel, clearly recognisable by its wattles, comb, and tail feathers. Its wings are spread, which is unusual for depictions of chickens, but most bizarre is the human face placed on its belly.

It is thought that this coin was inspired by Central Italian coins dating back to the late third century B.C. (Delestrée 1980: 55), but the themes of Classical art would have been readapted for use by these communities, not simply copied (MacDonald 2007: 493). The decision to produce this image and hybridise it with a human 
would certainly have been influenced by local interpretations of what a chicken is, resulting in a new image with a unique set of meanings attached to it (Aldhouse-Green 2004: 178). At least two coins of this type have been found by metal detectorists in Britain (Portable Antiquities Scheme numbers KENT12 and HAMP-B15408), and while it is impossible to be sure that they were deposited in antiquity, it does suggest that Mediterranean coins occasionally made their way to the far northern edge of the empire. Such copying is not an unusual concept, with the earliest gold coins from this part of Gaul thought to have ultimately taken their imagery from far-flung Macedonia and the coins of Philip II (Creighton 2000: 26).

A comparison of the Gaulish coin to one of the above Central Italian coins does show some similarities. Both have a helmeted, possibly female, head on the obverse and a chicken on the reverse. The Gaulish coin has round shapes corresponding to the locations of a starburst while the Italian example has a crescent. However, the chicken on the Campanian coin is more erect in the manner of modern breeds of gamecock like the Shamo and its wings are folded. The Gaulish coin's chicken, apart from the addition of a human face, has spread its wings and holds its head back. While the design of the later coin may have been influenced by the earlier one, it was not a slavish copy.

Delestrée suggested that the plump crop shown on some of the Campanian coins inspired the Belgic coin makers to fill in the space with a human face (Delestrée 1980: 56), but it is unlikely that such an unusual image would be created on a whim. It must have been born out of some aspect of Belgic culture, creating a local icon out of an imported image.

Accepting type DT 511 as the first of the Belgic cockerel coins, it is easy to see the other types as either derivatives or otherwise inspired by the same sources. While the imagery of the DT 511 coin is relatively naturalistic, some of the others become quite stylised and abstract, with DT 509 being perhaps the most extreme example.

The hybrid image is by no means universal, with types DT 510, DT 517, DT 518, and DT 521 having the bird without the face. Type DT 515 is unusual in having the human face at the edge of the coin, facing the nonhybridised chicken. Types DT 519 and DT 520 have two hybrid birds facing each other. Type DT 521 is the most deviant of the cockerel coins, not only having a significantly different form of chicken on the reverse, but also featuring a boar instead of a human face on the obverse.

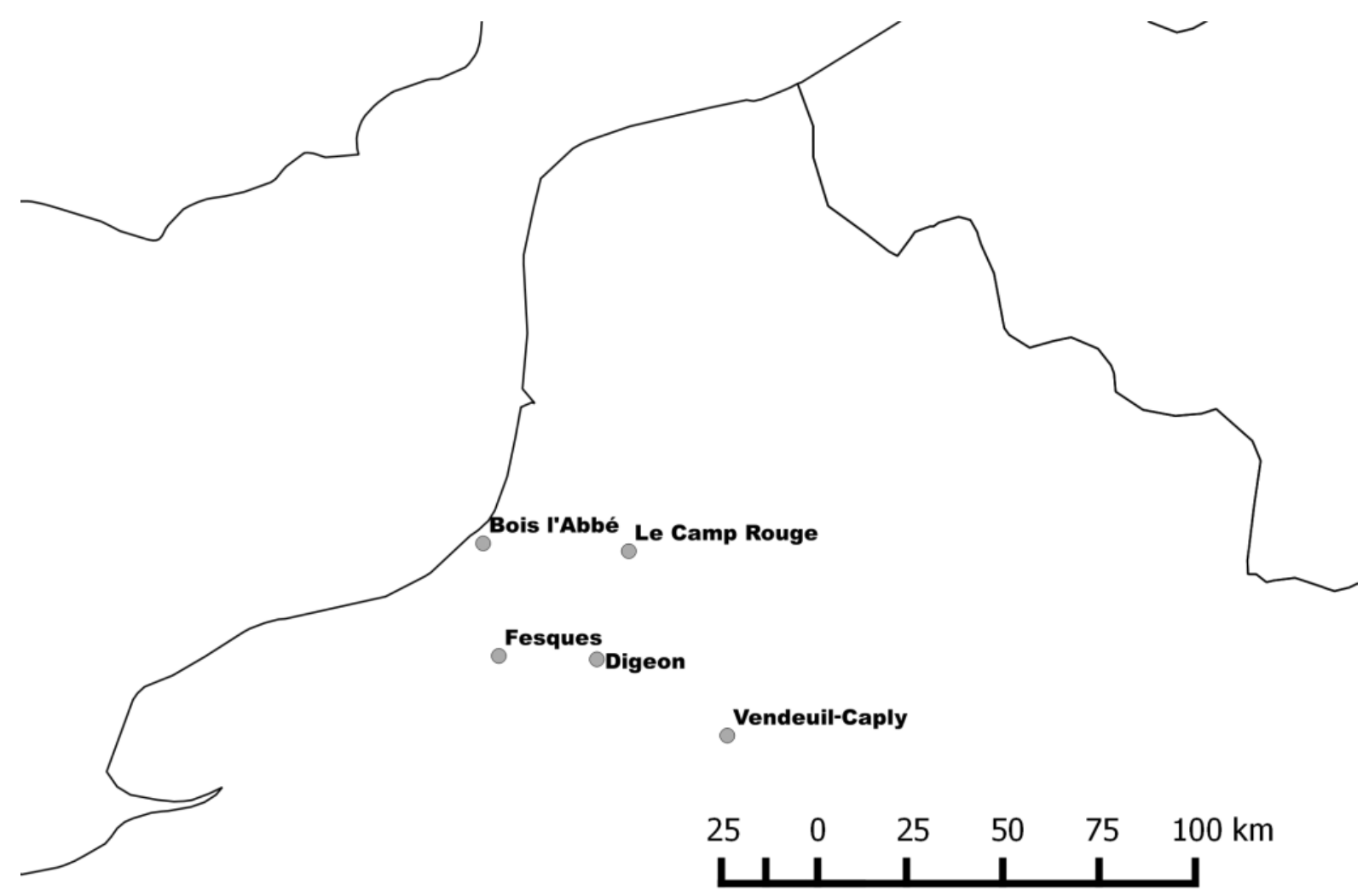

Figure 2: Locations of Late Iron Age temples where these coins were recovered. 
Nearly all of the coins in Gaul were recovered from Late Iron Age religious sites in Picardy and Normandy (Fig. 2). The most significant were Digeon, Fesques, Bois-l’Abbé, Camp Rouge, and Vendeuil-Caply, all of which had later Gallo-Roman religious activity. The vast majority of coins from these sites were recovered by metal detectorists, with the exception of Fesques, which limits contextual interpretation to the site level.

Table 1: Iron Age religious sites and the number of the coin types found there.

\begin{tabular}{|l|l|l|l|l|l|}
\hline $\begin{array}{l}\text { Coin } \\
\text { type }\end{array}$ & Digeon & Fesques & $\begin{array}{l}\text { Bois- } \\
\text { l'Abbé }\end{array}$ & $\begin{array}{l}\text { Camp } \\
\text { Rouge }\end{array}$ & $\begin{array}{l}\text { Vendeuil- } \\
\text { Caply }\end{array}$ \\
\hline DT 509 & 14 & 1 & & & 6 \\
\hline DT 510 & 1 & & & & \\
\hline DT 511 & 443 & 169 & 49 & 12 & \\
\hline DT 512 & 2 & 57 & 3 & & \\
\hline DT 514 & & & & 2 & \\
\hline DT 515 & & & & 1 & \\
\hline DT 516 & 19 & 1 & & 12 & \\
\hline DT 517 & & 1 & 34 & & \\
\hline DT 519 & 13 & 1 & & 3 & \\
\hline DT 521 & 1 & & & & \\
\hline
\end{tabular}

Known in the nineteenth century as the terre d'argent (land of money/silver, Delplace et al. 1986: 83), the temple site at Digeon (Somme) has the highest concentration of coins in Belgic Gaul (Delestrée and Delplace 1986: 19). Nearly 1,200 identifiable coins from this site, largely from museum collections and metal detectorists, were examined in one study (Delestrée and Delplace 1986). Coins with chickens on them were the most abundant type of bronze coin recorded there, especially the Bracquemont type, DT 511 (Table 1). Smaller numbers of other chicken coins were present, all of them minted locally, and all of them seem to be of a similar date, making for a remarkably homogeneous assemblage (Delestrée and Delplace 1986: 18-19). From Digeon, it is thought that chicken imagery spread to the other religious sites (Delestrée 1994: 27). One of these sites was Fesques, a large temple complex in use from the third century B.C. to the second century A.D. (Mantel 1997: 7). Many of the coins from this site were, fortunately, recovered during controlled excavations and therefore come from known contexts, most of which were within the main three structures on site (Delestrée 1997: 283). Most of these contexts were pits and ditches, and it is possible that the coins were redeposited within these features during later renovations to the site (Haselgrove 1999: 115), but it is also possible the coins may have been primary deposits of votive offerings. As with Digeon, the coins are mostly local and form a homogeneous group (Delestrée 1997: 285). Type DT 511 is likewise the most common type, followed by DT 512, which is a smaller variation of the Bracquemont type (Table 1).

The site of Bois l'Abbé, near Eu (Seine-Maritime), is another large sanctuary with a high concentration of chicken coins (Delestrée 2008). The numbers are smaller than the previous two sites, but DT 511 still dominates (Table 1). Here, however, type DT 517, which otherwise was only represented by a single example at Fesques, is the second most common. This coin lacks the human face on the chicken and appears less stylised than most of the others. Whether these differences indicate an earlier coin type or merely a different artistic tradition is unknown.

Le Camp Rouge near the town of Fontaine-sur-Somme (Somme) had a smaller, but more diverse, collection of coins (Delestrée 1987). Type DT 511 was still one of the two most common types, in equal abundance with type DT 516. Type DT516 was found in small numbers at Digeon and Fesques, but the relative proportions suggest a local prominence at this site. The coin bears similarities to both types DT 511 and DT 517, and is unusual in that a small lyre appears in front of the face on the obverse side. Although they appear in smaller numbers, this site also possessed the only examples of types DT 514 and DT 515 (Table 1).

The temple complex at Vendeuil-Caply is quite different from the others, having only six chicken coins in its assemblage and lacking type DT 511 entirely (Delestrée 1985). Here only type DT 509 was found, which only appears in small numbers at Digeon and Fesques. This type is perhaps the most stylised and abstract of the coins discussed here, with the shapes being made up of simple lines and dots. This site is the most peripheral of the group, and so may be located on the edge of the 'chicken zone', with different influences at play.

It has been suggested that during the Late Iron Age, religious sites such as these were where coins were minted (Delestrée and Delplace 1986: 19; Haselgrove 2007: 501). For 'tribal states', defining themselves around a group rather than a geographic point, such as a city, such sites would be ideal for this sort of centralised activity, and would have served as a geographic anchor for such a group (Collis 2007: 524-525). This would 
explain the high volume of coins and some of the variation between the sites. A site might be expected to have a large proportion of the coins minted there, including coins from the more important sites with which it was associated. The huge number of coins from Digeon may reflect a recovery/reporting bias rather than the status of the site, but it does appear to be a site of great importance for the chicken coins. The dominance of the possibly prototypical version (type DT511) of these coins, suggests that it may have been where they were minted, and possibly the original local source of this image.

A look at the list of types in Table 1 suggests possible local issues at the other sites and highlights the importance of type DT 511, even if it was not the earliest type. Fesques lacks any strong contender, with the possible exception of type DT 512, a smaller variation of type DT511. That both are often listed generically as 'Bracquemont type' makes it difficult to explore this particular deviation further.

Bois l'Abbé would appear to be the home of type DT 517, with only the Bracquemont types making an appearance alongside it. Le Camp Rouge is likely to have been where type DT 516 was minted, and possibly types DT 514 and DT 515, although they may represent coin types from other religious sites not included here. The coin catalogues of Vendeuil-Caply contained only type DT 509, so of these sites, it is the only likely mint. It appears that there may be a difference based on the river valleys, with Digeon, Fesques, and Bois l'Abbe all being along the Bresle River, and le Camp Rouge and Vendeuil-Caply being along the Somme's tributaries. This explains where the coins were found and their potential minting sites, but the question of when they were minted remains. Unfortunately, the Western zone coinage is difficult to date (Haselgrove 1999: 160). They appear to fall into Haselgrove's Stage 3 (125-60 B.C.) or Stage 4 (60-20 B.C.), with Stage 4 being the most likely. Delestrée has dated them to after the Gallic War (Delestrée 1980: 47), with the provenanced coins from Fesques coming from buildings dating to the second half of the first ${ }^{t}$ century B.C. (Delestée 1997: 285), but he has at least once suggested they may have been in circulation before the Roman conflict was resolved (Delestrée and Delplace 1986: 19). Haselgrove has noted that it is particularly difficult to determine which changes in this region were due to the social changes during the war versus those that came after (Haselgrove 1999: 149). A mid to late first century B.C. date for these coins appears to be as close as it is possible to estimate for now.

\section{Britain}

The situation in Britain is quite different, with only a single chicken-human hybrid coin type, type ABC 737, the Chichester 'cock bronze'. It has been examined in the most detail by Cottam (1999), who determined that minor variations among coins of type ABC 737 suggested at least three distinct minting events potentially resulting in the creation of hundreds of thousands of coins. They are thought to have been copied from the Gaulish coins, possibly more than once, with early examples being influenced by types DT 511 and DT 509 (Cottam 1999: 10) and some later ones seemingly copying elements of types DT 517 and DT 518 (Cottam 1999: 12).
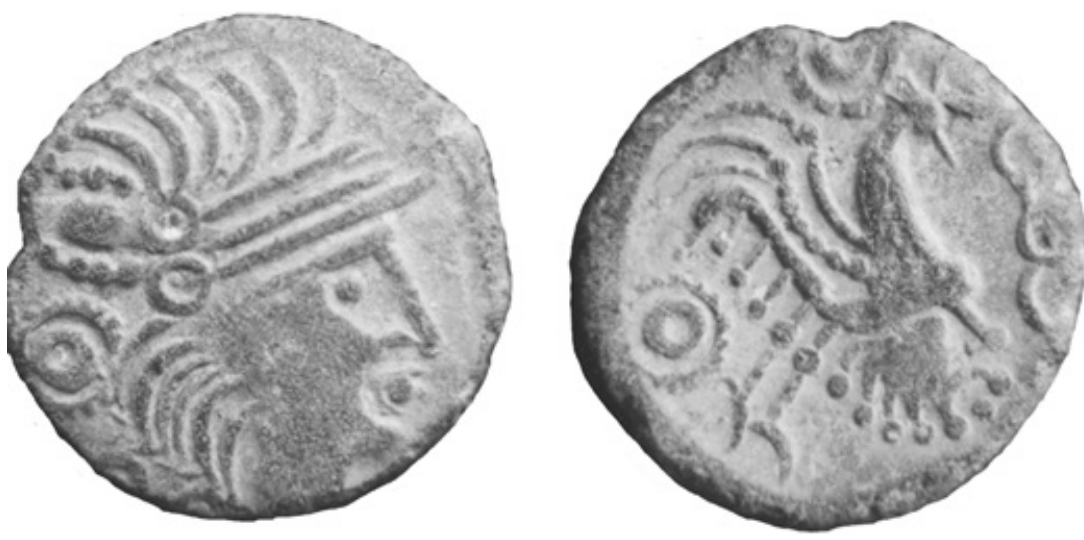

Figure 3: British 'cock bronze'. CCI-3072. Courtesy Oxford University and the Portable Antiquities Scheme (CC-BY).

The images on the coin are more stylised and abstract than many of the Gaulish examples (Fig. 3), with a human head wearing some kind of helmet or headdress on the obverse and a chicken with a human face on its stomach on the reverse. Here the face appears to be bearded, with the line of feathers merging into a beard towards the front of the bird.

The exact ancestry of the British coin is difficult to determine, but it is clearly related to the Gaulish examples and can be ultimately traced back to the theoretical prototype DT 511. Without the intervention of the British Channel, it would most likely have been classified as another, more stylised Bracquemont derivative.

The distribution pattern of the Chichester cock bronzes is very different from the Gaulish coins, however. It is made up of approximately 65 individual coins found across southeast Britain, albeit with a heavier 
concentration around Chichester, rather than a few sites with large deposits (Fig. 4). None of the known examples came from a secure context, and so it is difficult to discuss their locational context as anything but points on a map.

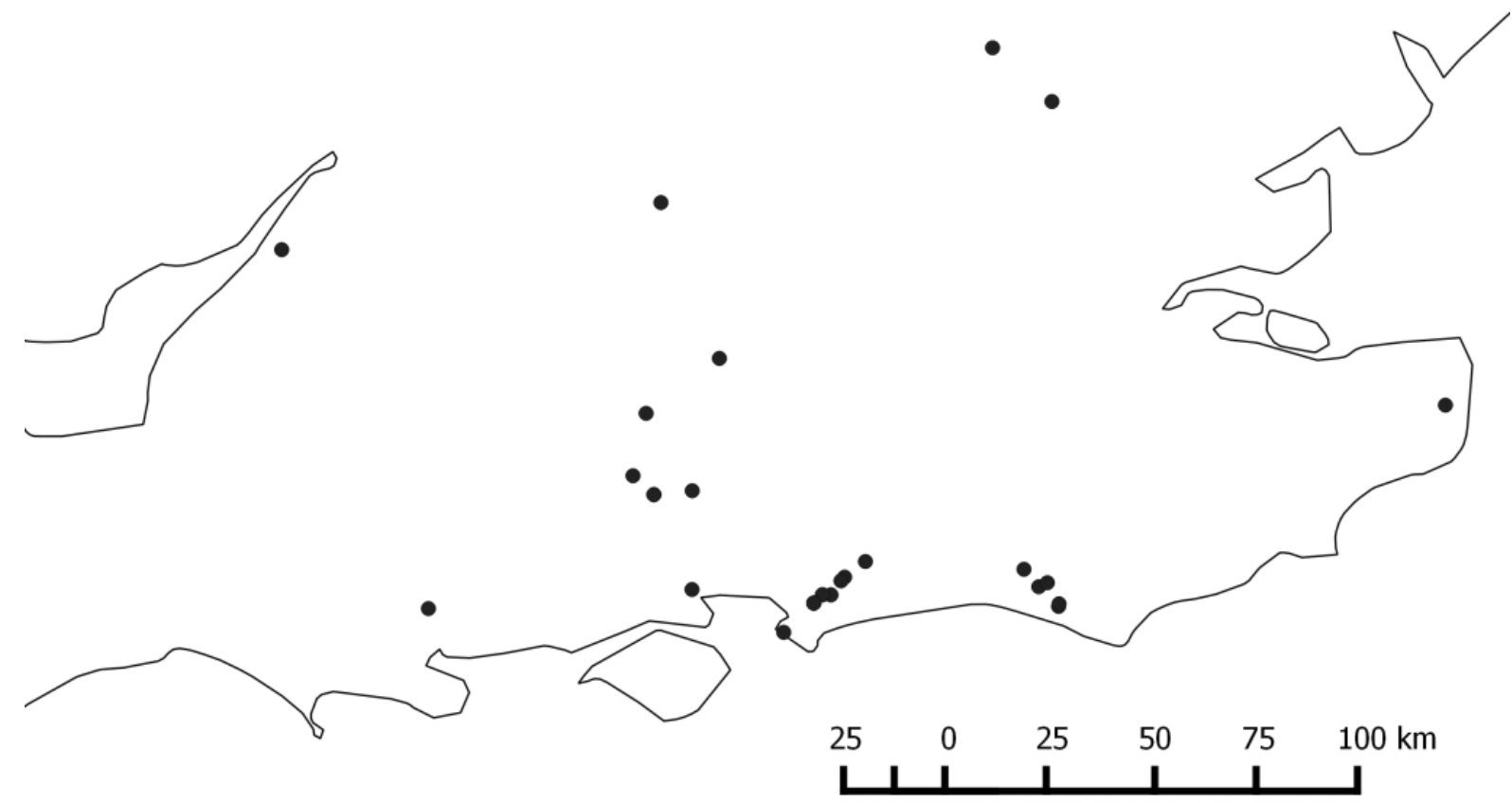

Figure 4: Find spots of British cock bronzes.

Despite the presence of a number of religious sites near Chichester, including Hayling Island (Briggs et al. 1993) and Westhamptnett (Fitzpatrick 1997), both in the area of highest concentration of these finds, none of the coins have been unambiguously recovered from within their confines, and certainly not in high numbers. While the primary structures on these sites tend to be poor in finds, they have produced some artefacts in the surrounding features (Hamilton 2007: 94). Although the images on the coins are similar, it appears that they were not used and deposited in the same way as they were in Belgic Gaul.

As with the Gaulish coins, it is difficult to determine an exact date for the British examples. If they are derived from Gaulish coins, as seems likely, then they will naturally post-date them, but this is of little help due to the limited chronology available. A date of the late first century B.C. seems most likely, but Haselgrove (1999: 165) has noted that with the early use of struck bronze in that part of Gaul it may be necessary to consider an earlier date for these coins as well.

The lack of coins at Hayling Island could help in this respect. The coin evidence from the temple suggests it was initially in use around 30-25 B.C., followed by a gap until the appearance of coins from just before the Claudian invasion (Creighton 2000: 195). It seems reasonable to suggest that the Chichester coins went out of use either before the temple was established or that they were minted and circulated between these periods of use.

\section{Discussion}

Having addressed the background of coins as objects, we can now discuss the iconography of the hybrid chicken and what it means. While there may be more to be learned from a purely numismatic perspective, such an approach is beyond the scope of this study. The question being asked here is, why a chicken, and why add a human face to it? While recent studies have shown that interest in chickens in Iron Age Europe was greater than previously thought (Maltby et al. 2018), Late Iron Age faunal assemblages from this particular region of England usually have, at best, only a small percentage of chicken bones (Hambleton 2008: 27), and so can offer little in the way of answers. It is important to note that these coins represent the earliest depictions of chickens created in northern Gaul and Britain. While the foreign coins discussed above may have been known to the people in the areas where these coins were minted, they were all products of another culture. If they influenced 
the art of native craftspeople, it would have built upon pre-existing notions of what a chicken was and not simply replaced it with that of the original creators.

These images were created during a time of great change, with a new and relatively sudden pressure from a powerful, expanding empire leading to war and eventual conquest, but there is also an introduction of new goods and ideas, which, it must be said, may not all have been viewed as 'Roman', but merely exotic (Haselgrove 2007: 512). Without accurate dating, it is difficult to determine exactly where these coins fit into this picture. If they were minted prior to Caesar's victory over the Belgic tribes, their meaning might be quite different than if this happened afterwards, or even during the later uprisings. And what of the British examples, which pre-date the arrival of Roman bureaucracy? What effect did this difference in Roman relations have on how these images were viewed?

Philip MacDonald has argued that 'exploring the potential artistic nexus provides a useful way of thinking about the possible roles of art within the social relations of Iron Age societies' (2007: 494). Here, consideration of different agents and forms of agency and how they inter-relate (the agencies of animals, coins, images, humans, and the location and social context of object manufacture, circulation, and use) has helped to develop routes for understanding and explaining the chicken-human imagery. Consideration of the relationships between different agents, has enabled exploration of the impact that the use of the chicken-human image on coinage may have had on two different local groups of people as they negotiated their place and identity within the Roman empire.

As Gaul appears to be the birthplace of this image, any investigation should begin there. This region does not appear to have any unusual relationship with chickens. The known animal bone assemblages are unremarkable, containing neither high numbers nor unusual specimens (Méniel 1986; 1997; 2008). They appear on no other iconography from this period, and the representation of chicken-related artefacts in this particular area during the Roman period is unremarkable (Feider 2017). Whatever the source of the hybrid chicken, it does not appear to have left any sign of great affinity in the faunal record or subsequent material culture. However, these images are a fantastic way to examine the influence animals have on the people who keep them that might not be visible in the faunal remains. It is impossible to interact with an animal at any meaningful level and not be changed by that experience (Armstrong Oma 2010; Sykes 2014: 5). Something of the animal seeps into the social consciousness.

Exploring the agency of objects, and indeed the agency of animals, in the past can be difficult, especially if it is not clear how the objects or animals were used or perceived, or how their use and perception may have changed over time or in different circumstances (Harris and Cipolla 2017: 78-80). During the Late Iron Age and Early Roman period, there were changes in how coins were used as these cultures became more integrated with Roman trade networks (Haselgrove and Krmnicek 2012: 241), and those changes may have occurred during the time these coins were in use. In this case, if we consider the coins as 'secondary agents' (Gell 1998: 20) the uncertainty of how the coin-makers intended the coins to be used and their imagery understood is a limiting factor, but it is still possible to tease out some of their meaning or purpose.

If these coins were being minted at religious sites, as discussed above, then an additional question is whether these objects took on a religious significance. As a geographic focus, a sanctuary may have played many roles, minting among them, which may not have been seen as religious in nature. The large deposits of coins on these sites are certainly suggestive of the objects' nature as a votive offering, but to what extent were they seen as religious themselves? It is also possible that these were undistributed coins, deposited either as waste, possibly as secondary deposits, but given such large numbers across a site this seems unlikely. At later Mithraic sites, such as Tienen, Belgium, large deposits of animal bones and associated feasting material have been interpreted as a sort of ritual memory of the act, and with processions of worshippers all making their own deposit (Martens 2004: 44-45). Possibly some coins from each batch created were buried to commemorate the act of creation, collection, or pilgrimage. The lack of this type of deposit on British temple sites suggests that either coins were not minted there or that there was a difference in their use as votive objects at the time they were made. The nature of the coins as an offering could have more than one explanation, as well. While they may have been of a propitiatory nature, sacrificing an object with a value attached to it in return for some blessing, even this could have variations. Pilgrims to one of these sites may have obtained a coin to use as an offering for a safe journey, or the coins may have served as a sort of token in lieu of another, more traditional offering. On a less individual scale, if the coins were collected from this site for use or redistribution elsewhere, perhaps one or two were left behind from each batch as a form of offering or to create a symbolic link back to an important site.

Regardless of why coins were deposited on these sites, the presence of many different types of coins suggests that the images they contained were of less importance than the objects as a whole. If so, they were not deposited because they were chickens, but because they were coins, and the search for insight into the chicken imagery will have to move elsewhere.

The coin assemblages from these sites and across the region suggest a relatively insular community, with few of these types travelling very far and few coins from other groups making their way in (Delestrée 1997: 285; Haselgrove 1999: 160-161). Whether this was because these people turned inwards during or after the 
events relating to the coming of Julius Caesar, or because they had an underdeveloped trading network making little use of coins between territories is uncertain. It does bring to mind Caesar's statement that some groups in this region refused to trade (Caes. BGall. 2.15), but those groups, namely the Nervii, were found further north than this region.

With the coins as a whole having a strong local focus, it must be asked whether their iconography shares a similar introspection, with images selected because of some strong local cultural connection. It is time to take a closer look at the images themselves and see if they can reveal their meaning.

The use of the chicken, regardless of its hybridisation, is immediately striking, as it is not an animal commonly depicted on coins. While the inspiration may have come from Mediterranean coins, there must have been some attribute associated with the bird to make it worth selecting for duplication. Humans and animals cannot coexist without both influencing the other (Armstrong Oma 2010), and the people who created these images would have made space in their cultural lexicon for chickens and subsequently expressed it, in some fashion, through depictions such as these. The difficulty is in interpreting them in their context.

The chicken, which is most commonly assumed to be a male because of its physical features, is reared back with its wings spread. While often unclear, on some coins it appears that its beak could be open, although the wattles and lower beak can be hard to differentiate (e.g. types DT 516 and DT 517, Fig. 1). Could it be an image of a cockerel stretching its wings and crowing? Although the designs on the coins reflect a conscious decision on the part of the coin-maker, from a posthuman perspective the bird has agency to influence the choice of image by the human artist; the final image communicates the artists' perception of chickens, as influenced by their experience of the bird. The cock's crow would certainly have been a strong mental association amongst people familiar with the bird. The depiction of wings on a chicken is unusual, therefore, is the presence of wings important, with them spread to ensure their visibility?

If the bird is crowing, it could indicate an association with dawn, the sun, or light in general. As some of the earliest literary records of chickens relate to crowing (Arnott 2007: 10) and solar imagery is fairly common on coins from this period (Creighton 2000: 42), an early depiction doing the same would not be unexpected. Suns or starburst symbols are quite common on coins of this era, and the addition of another solar symbol might not be implausible. Whether a solar connection is intended or not, a closer look at some of the coin types adds weight to the idea of sound being an important component of this image. Some of the coins have unusual curvilinear shapes in front of the chicken. This shape appears on type DT 511, but is often at or just off the edge of the coin. It is more pronounced on types DT 510, DT 516, and DT 517 (Fig. 1).

On the obverse side of these coins, the human head also has an unusual set of curves in front of it, appearing to emerge from the person's mouth. On type DT 516 this shape is less abstract and takes the form of a lyre. Could the shape be a depiction of speech or song? If so, are the lines on the other coin types a more abstract representation, perhaps the breath that carries the sound or the sound itself? Similar symbols in front of a cockerel are suggestive of a shared importance of sound. Of course, these birds do not only crow at first light, and the sound may not suggest the arrival of dawn, but another event that makes them vocal; being victorious.

Images of cockerels are often associated with combativeness and victory, particularly in older works (for example, Bruneau 1965). The stance of the figure in these images is not particularly evocative of a bird in combat, however, although type DT 510, where the chicken appears to be leaping with its feet extended in front of it, is an exception. Even if the image is not one of combat, it may still be meant to invoke images of it. Although organised cockfighting is almost impossible to detect archaeologically, people would still have been aware of the cockerel's natural behaviour and could have incorporated that into their cultural concept of what a chicken is. It could be the cockerel is not crowing for the dawn, but for combat. Against the background of the Gallic War this association becomes quite interesting, but its exact interpretation could vary depending on when exactly these coins were in use. The use of the cockerel as a martial symbol during a conflict needs little explanation, but how could it still be used in defeat?

Up to this point, the use of tribal names has been largely avoided because of the issues surrounding their use (Haselgrove 1999: 119; Isayev 2010: 224). However, it could now be informative to bring in one particular group to explore this association further. This region includes the land of the Bellovaci tribe, who fought against Caesar and later rebelled against Roman rule. They are often associated with these coins and probably produced the original, type DT 511.

The lack of precise dating or a deep understanding of the history of this region on such a small timescale limits interpretation, but enough of a general history is known to examine one possibility. The insular nature of the assemblages containing these coins could indicate a society under pressure from external forces. During the initial war with Caesar or during an anti-Roman uprising this makes sense, and the selection of an animal associated with combat is also appropriate. However, if the coins were minted after the Gallic War, as seems likely, then the image offers an intriguing new meaning.

Miranda Aldhouse-Green (2004: 15) has suggested that animal behaviour may be one route to understanding the human-animal hybrid symbolism. In some modern cockfighting cultures, such as that of the Canary Islands, the way a bird loses is as important as if it wins (Ontillera 2016). A cockerel that loses well is more deserving of 
respect than one that 'turns chicken'. In the case of the Gallo-Roman chicken-man hybrids this 'plucky chicken' behaviour in defeat is a rather more subtle and subversive message than the overtly aggressive fighting cock. If the Bellovaci, or whatever group was responsible for minting these coins, shared that belief, then the image may be a proud symbol of a noble defeat. They may have been conquered by the Romans, but they went down fighting and could still raise their heads high. Such a sentiment could have formed a central conceit of this group's post-conquest identity and helped fuel later revolts.

Animal-human hybrid imagery occurs in other examples of Gallo-Roman art. Aldhouse-Green (2004: 15, 79) has discussed two antlered human female bronze figurines from Roman Gaul, considering both the transgression of species and (especially) gender boundaries. As with the interpretation of the merged chickenhuman depicted on the coins, she highlights the importance of seeking meaning within the image form itself, but also stresses the need to consider meaning in relation to both the producers and consumers of such images. This aspect of the coinage can be appreciated through Gell's (1998: 6) discussion of the agency of objects whereby art (or images) can be seen as a 'system of action, intended to change the world rather than encode symbolic propositions about it'. As such, we should perhaps be less concerned with what the chicken images mean or symbolise and more concerned with their secondary agency and what these coins were intended to do. In the context of the Bellovaci, what reactions, or more importantly, what actions, might these coins have helped provoke? Did they instil a sense of pride and fortify the defeated into further acts of defiance and revolution? What of the effect on other groups coming into contact with these coins? Did the images on the coins communicate insult or challenge to this group? Of course, it is impossible to know for sure if this is what happened, but it is an intriguing possibility.

While this may explain why a chicken was used, it does not address why the human face appears on so many of these coins. It has been suggested that hybrid images themselves hint at instability and violence (AldhouseGreen 2004; 149), but the image must have some deeper meaning. Such hybrids can be gods, spirits, or magicians (Aldhouse-Green 2004: 150; Kristoffersen 2010: 264-265), which may be the case here. While the image may not necessarily be a true hybrid creature, perhaps representing a person wearing a headdress of some sort, the ultimate result is a human and chicken being linked together on a symbolic level. Beyond even a normal depiction of an animal, this blurring of the boundaries between human and animal demonstrates a deeper cultural understanding between chickens and humans.

Creighton (2000: 42-47) has suggested that some of the more abstract and unusual images and shapes on Iron Age coins were meant to capture the visual aspects of a trance state. While he only mentioned these coins in passing, he did discuss coins from the same region that feature a human-headed horse as possibly trying to capture the same imagery, which Aldhouse-Green has discussed elsewhere as a response to the Gallic War (2004: 163). This raises the possibility that the chicken-man may be linked to some form of shamanistic practice, perhaps reinforcing a cultural connection to some aspect of the bird. Some people have reported synaesthesia, or seeing sounds, while under the effect of psychotropic drugs (Abel 1985: 111), which adds weight to the idea of sounds being depicted.

Even if it did have psychotropic influences, such a hallucinogenic component is not necessary, and the image could also have had a more mundane source. Perhaps it represents an individual with some intimate connection with chickens. Maybe it references a similarity of name, or even a nickname, and naming can be a complex issue, conveying behaviours, histories, and stories, sometimes even in riddle form (Ingold 2011: 165-176). If so, then the meaning is lost to time. It may also represent a previously aniconic deity, taking on a more visible form in this new medium, who might later evolve into a local version of a god like Mercury. Whatever the case, too much of the cosmological context of the image is lost to be sure. If the curvilinear lines are meant to evoke sounds, then perhaps it is a reference to a famous oration or song. One can imagine a leader during this period speaking of a new dawn for his or her people, with images being created to evoke the same response.

In Britain, the image on the coin is too similar to have developed independently. This region is known to have had close contacts with the Belgic people, with even earlier gold coins making their way back and forth between them (Haselgrove 1999: 119; de Jersey 2006: 126-127). The image was adopted by people living in and around Chichester and the coins spread across much of southeast England, but with none of the large temple deposits seen in Gaul. This wider distribution and lack of highly concentrated deposits at religious sites show the coins' agency was not the same as it was across the Channel and suggests a difference in culture, and possibly in meaning. It also demonstrates that despite their similar appearance, the agency of the British coins and the impact of their imagery on people interacting with them in this context is independent from the original intent of their French counterparts.

Without the pressure of the Romans, perhaps the British tribes were less insular, with base metal coinage taking a greater role in long distance trade. If coins were being minted at other, non-religious, sites then they may have been less convenient to use as votive offerings. It is intriguing that none of these coins have yet been found at the Hayling Island temple, which is otherwise quite similar to the Belgic examples (Briggs et al. 1993: 
41).

The image on the Chichester coin is more simplified than many of the Gaulish types, but it is still recognisably the same image. This could indicate a shared deity, mythical figure, or culture hero; perhaps even a ruler associated with the chicken. However, if it was tied into a post-Caesar identity, then surely some of that would be lost amongst people who had had only minimal contact with these southern people. It is possible that there was a fundamentally different dialogue between humans and chickens in Britain that changed the meaning altogether.

The role of an object can change over time, especially as it moves between different cultures (Harris and Cipolla 2017: 80-84). Just as the chicken itself took on a new role when it was introduced to these regions, so did the hybrid chicken that appeared on these coins. As mentioned above, the difference in deposition practices suggests coins themselves may have behaved differently.

While any number of Belgic elites may have crossed to Britain during this period, bringing their iconography with them, one figure in particular presents an intriguing possibility. Commius is famously linked with both of these regions on the assumption that the 'Commios' appearing in inscriptions on British coins is either the same person or a relative. His personal history fits the ideas behind the source of the image quite well. He was familiar with the Roman world and later allied with the Bellovaci to fight against the Romans. Then, possibly to put a still useful but dangerous figure out of the way, he may have been set up as a client-king in the region of southern Britain where these coins were made (Creighton 2000: 60-64). If the Hayling Island temple does, in fact, represent a Commian dynastic cult, built either late in, or soon after, his reign (Creighton 2000: 192), then could the Chichester coins be an issue from earlier in his career, perhaps soon after his arrival from Gaul and minted in large numbers as a form of propaganda?

Regardless of how it arrived, it is not clear how much the meaning behind the Gaulish image was carried over. This region of England appears to have casually adopted objects and traditions from across northern Gaul (Hamilton 2007: 98). While the meaning may have remained intact, it could also have been adopted as a sign of kinship with the groups that invested more of their own culture into it. Whatever the case, it would surely have carried a positive association in order for it to be adopted.

\section{Conclusion}

With the arrival of Julius Caesar and the first steps in becoming a part of an increasingly multicultural Roman world, this was a time of great social and political change, with war, defeat, revolt, and eventual acceptance. Without being able to pinpoint exactly when the coins were created in this process, it is difficult to extract the history of the iconography. However, although they may have been influenced by coins from the far-flung south, these images were forged out of a sense of local identity, possibly after the initial defeat of these groups by Caesar's legions. It is the connection between these people and the chicken, which otherwise appears to have held little importance on the sites where these coins were found and produced, that lies behind this image, but without further evidence, it is difficult to say what meaning the hybrid chicken had. It could intentionally or inadvertently have encouraged cohesion within a community and revolt against those outside the community. It could have been an image of nobility in defeat, a representation of a god from a dream state, a reference to a local hero, or intended to recall a speech or song. This latter option is particularly intriguing and could tie into any of the others, and these coins may represent an early depiction of sound in a visual medium. Whatever the reason, 'chicken' would have come with a package of images, meanings, myths, memories, and sounds. By creating this image, these people forged a connection between this concept of a chicken and 'us', creating a new symbol which would then begin accreting meanings as its own entity.

The relationship between the coins of Belgic Gaul and Britain is also obscured, but they share an obvious ancestry. Lacking the pressures of northern Gaul, the image may have taken on another meaning in Britain, and there are certainly differences in where they have been recovered. How much these distributions reflect underlying cultural variation or merely differences in metal detecting legality and reporting and excavation is unclear, but the lack of large temple deposits in Britain seems to be genuine.

Until recently, the chicken was often the forgotten domesticate, although over the last few years research has shown their importance as both a source of food and as a symbol (Sykes 2012; Gordon et al. 2015; Fothergill 2016; Colonese et al. 2017; Feider 2017; Bennett et al. 2018; Maltby et al. 2018). They scratch away in the dust while the larger mammals dominate archaeology's bone assemblages and thoughts. They occupy a strange space in the world of humans, solely occupying the domestic sphere while cows, sheep, pigs, and horses venture out into the wilder stretches of human settlement. This gives them a strong connection to their human keepers, one that will have inserted the species into the cultural cosmology of any people who keep them. By close study of artefacts like these, it is possible to get a glimpse into that abstract world of meaning.

Something drove the people of Belgic Gaul and Britain to celebrate the chicken in the form of the hybrid chicken-man on these coins. It is poetic that after over two millennia, the Gallic Rooster still appears on coins in this region. 
Department of Archaeology and Anthropology, Bournemouth University

\section{Bibliography}

\section{Ancient Sources}

Caesar (Translated by C. Hammond 1996). Seven Commentaries on the Gallic War, with an Eighth Commentary by Aulus Hirtius. Oxford: Oxford University Press.

\section{Modern Sources}

Abel, E.L. 1985. Hallucinogens. In E.L. Abel (ed) Psychoactive Drugs and Sex. New York: Springer.

Aldhouse-Green, M.J. 2004. An Archaeology of Images: Iconography and Cosmology in Iron Age and Roman Europe. London: Routledge.

Armstrong Oma, K. 2010. Between trust and domination: social contracts between humans and animals. World Archaeology 42: $175-187$.

Arnott, W.G. 2007. Birds in the Ancient World from A to Z. London: Routledge.

Bennett, C., Thomas, R., Zalasiewicz, J., Edgeworth, M., Williams, M., Miller, H., Coles, B., Foster, A., Burton, E. J. and Marume, U. 2018. The broiler chicken as a signal of a human reconfigured biosphere. Royal Society Open Science 5 (12): 180325.

Braidotti, R. 2018. A Theoretical Framework for the Critical Posthumanities. Theory, Culture \& Society (Special Issue: Transversal Posthumanities): https://doi.org/10.1177/0263276418771486

Briggs, D., Haselgrove, C. and King, A.C. 1993. Iron Age and Roman coins from Hayling Island temple. British Numismatic Journal 62: 1-62.

Bruneau, P. 1965. Illustrations antiques du coq et de l'ane de Lucien. Bulletin de Correspondance Hellénique 89 (2): 349 357.

Colonese A.C., Lucquin, A., Guedes, E.P., Thomas, R., Best, J., Fothergill, B.T., Sykes, N., Foster, A., Miller, H., Poole, K., Maltby, M., Von Tesch, M. and Craig, O. 2017. The identification of poultry processing in archaeological ceramic vessels using in-situ isotope references for organic residue analysis. Journal of Archaeological Science 78: 179-192.

Collis, J. 2007. The polities of Gaul, Britain, and Ireland in the Late Iron Age. In C. Haselgrove and T. Moore (eds) The Later Iron Age in Britain and Beyond. Oxford: Oxbow Books: 523-528.

Cottam, G.L. 1999. The 'cock bronzes' and other related Iron Age bronze coins found predominantly in West Sussex and Hampshire. British Numismatic Journal 69: 1-18.

Creighton, J. 2000. Coins and Power in Late Iron Age Britain. Cambridge: Cambridge University Press.

de Jersey, P. 2006. Belgic coins in Britain. In P. de Jersey (ed) Celtic Coinage: new discoveries, new discussion. Oxford: British Archaeological Reports, International Series 1532: 117-137.

Delestrée, L.-P. 1980. Les monnaies « au coq » frappées en Gaule belgique. Revue Numismatique 22: 33-62.

Delestrée, L.-P. 1985. Les monnaies gauloises du temple des «châtelets» à Vendeuil-Caply (Oise). Revue Archéologique de Picardie 1-2: 51-64.

Delestrée, L.-P. 1987. Les monnaies gauloises du Camp Rouge (Hallencourt-Fontaine-sur-Somme, département de la Somme). Revue Archéologique de Picardie 3-4: 51-60.

Delestrée, L.-P. 1994. La numismatique gauloise en Gaule Belgique. Problématique et axes de recherche. Revue Archéologique de Picardie 3-4: 19-30.

Delestrée, L.-P. 1997. Les monnaies gauloises en contexte du sanctuaire de Fesques. In E. Mantel (ed) Le sanctuaire de Fesques Le Mont du Val aux Moines'(Seine Maritime). Berck-Sur-Mer: CRADC: 283-294.

Delestrée, L.-P. 2008. Inventaire raisonné des monnaies gauloises. In M. Mangard (ed) Le Sanctuaire Gallo-Romain du Bois l'Abbé à Eu (Seine-Maritime). Lille: Revue du Nord: 209-233.

Delestrée, L.-P. and Delplace, C. 1986. Les monnaies gauloises de Digeon (Somme). Les ramassages de surface: première approche statistique. Revue Archéologique de Picardie 1-2: 13-22.

Delestrée, L.-P. and Tache, M. 2002. Nouvel Atlas des Monnaies Gauloises, I: de la Seine au Rhin. Saint-Germain-en-Laye: Éditions Commios.

Delplace, C., Jobic, F., Méniel, P. and Rapin, A. 1986. Le sanctuaire de Digeon, commune de Morvillers- Saint-Saturnin (Somme): Relation préliminaire aux fouilles de 1983 à 1985. Revue Archéologique de Picardie 3-4: 83-98.

Feider, M.P. 2017. Chickens in the Archaeological Material Culture of Roman Britain, France, and Belgium. PhD Thesis. Bournemouth University.

Ferrando, F. 2013. Posthumanism, Transhumanism, Antihumanism, Metahumanism and New Materialisms: Differences and Relations. Existenz 8 (2): 26-32.

Fitzpatrick, A.P. 1997. Archaeological Excavations on the Route of the A27 Westhampnett Bypass, West Sussex, 1992, volume 2: the Late Iron Age, Romano-British, and Anglo-Saxon cemeteries. Salisbury: Trust for Wessex Archaeology Report 12.

Fothergill, B.T. 2016. Urban Animals: Human-Poultry Relationships in Later Post-Medieval Belfast. International Journal of Historical Archaeology: 1-27.

Gell, A. 1998. Art and Agency: An Anthropological Theory. Oxford: Oxford University Press.

Gordon, R., Thomas, R. and Foster, A. 2015. The health impact of selective breeding in poultry: a probable case of 'creeper' chicken (Gallus gallus) from 16th-century Chester, England. International Journal of Paleopathology 9: 1-7. 
Hambleton, E. 2008. Review of Middle Bronze Age - Late Iron Age Faunal Assemblages from Southern Britain. Portsmouth: English Heritage.

Hamilton, S. 2007. Cultural choices in the 'British Eastern Channel Area' in the Late Pre-Roman Iron Age. In C. Haselgrove and T. Moore (eds) The Later Iron Age in Britain and Beyond. Oxford: Oxbow Books: 81-106.

Harris, O.J.T. and Cipolla, C. 2017. Archaeological Theory in the New Millennium: Introducing Current Perspectives. London/New York: Routledge.

Haselgrove, C. 1999. The development of Iron Age coinage in Belgic Gaul. The Numismatic Chronicle 159: 111-168.

Haselgrove, C. 2007. The age of enclosure: Later Iron Age settlement and society in northern France. In C. Haselgrove and T. Moore (eds) The Later Iron Age in Britain and Beyond. Oxford: Oxbow Books: 492-522.

Haselgrove, C. and Krmnicek, S. 2012. The Archaeology of Money. Annual Review of Anthropology 41: 235-250.

Ingold, T. 2011. Being Alive: Essays on Movement, Knowledge and Description. Routledge: London.

Isayev, E. 2010. Unintentionally being Lucanian. In S. Hales and T. Hodos (eds) Material Culture and Social Identities in the Ancient World. Cambridge: Cambridge University Press: 201-226.

Kristoffersen, S. 2010. Half beast-half man: hybrid figures in animal art. World Archaeology 42 (2): 261-272.

MacDonald, P. 2007. Perspectives on insular La Tène art. In Haselgrove C \& Moore T (eds) The Later Iron Age in Britain and Beyond. Oxbow.

Maltby, M., Allen, M., Best, J., Fothergill, T. and Demarchi, B. 2018. Counting Roman chickens: multidisciplinary approaches to human-chicken interactions in Roman Britain. Journal of Archaeological Science 19: 1003-1015.

Mantel, E. 1997. Le Sanctuaire de Fesques Le Mont du Val aux Moines'(Seine Maritime). Berck-Sur-Mer: CRADC.

Martens, M. 2004. The Mithraeum in Tienen (Belgium): the small finds and what they can tell us. In M. Martens and G. De Boe (eds) Roman Mithraism: the evidence of the small finds. Brussels: Instituut voor het Archeologisch Patrimonium: 25-56.

Méniel, P. 1986. Les restes animaux du sanctuaire de Digeon. Revue Archéologique de Picardie 3-4: 109-113.

Méniel, P. 1997. La faune du sanctuaire de Fesques "le mont du Val-Aux-Moines". In E. Mantel (ed) Le Sanctuaire de Fesques Le Mont du Val aux Moines'(Seine Maritime). Berck-Sur-Mer: CRADC: 283-294.

Méniel, P. 2008. Les restes animaux du sanctuaire du Bois l'Abbé. In M. Mangard (ed) Le Sanctuaire Gallo-Romain du Bois l'Abbé à Eu (Seine-Maritime). Lille: Revue du Nord: 291-294.

Morris, J. and Maltby, M. 2010. Integrating Social and Environmental Archaeologies: Reconsidering Deposition. British Archaeological Reports International Series S2077. Oxford: Archaeopress.

Overton, N. J., and Hamilakis, Y. 2013, A manifesto for a social zooarchaeology. Swans and other beings in the Mesolithic, Archaeological Dialogues 20 (2): 111-136.

Ontillera, R. 2016. Chicken Cultures and Male Identities in the Canary Islands. Unpublished conference paper. University of Roehampton Research Seminars. Roehampton University: Centre for Research in Evolutionary, Social and InterDisciplinary Anthropology (CRESIDA).

Pitt, J., Gillingham, P., Maltby, M., Stafford, R. and Stewart, J. 2019. Changing cultures, changing environments: a novel means of investigating the effects of introducing non-native species into past ecosystems. Journal of Archaeological Science: Reports 23: 1066-1075.

Russell, N. 2014. Social zooarchaeology. In C. Smith (ed) Encyclopedia of Global Archaeology. New York: Springer: 67616765.

Sykes, N. 2012. A social perspective on the introduction of exotic animals: the case of the chicken. World Archaeology 44: 158169.

Sykes, N. 2014. Beastly Questions: Animal Answers to Archaeological Issues. London: Bloomsbury. 